Figure 4A

Anti-Mpphot

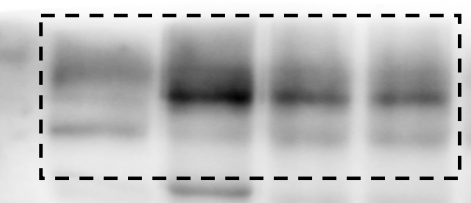

CBB staining 
Figure 4D

Anti-Mpphot

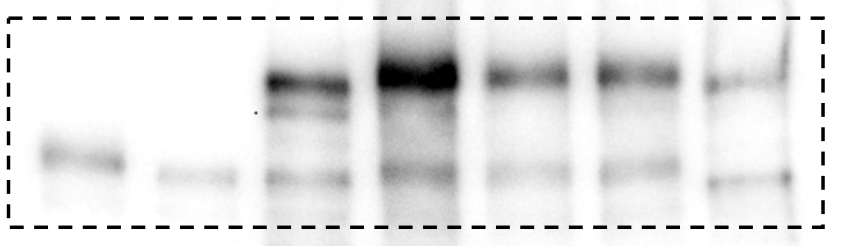




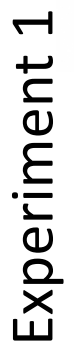

\section{CBB staining}

$0 \frac{5^{\circ} \mathrm{C}}{369}$

\section{Anti-Histone H3}

$$
0 \frac{5^{\circ} \mathrm{C}}{369(h)}
$$

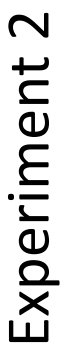

$$
0 \frac{5^{\circ} \mathrm{C}}{369}
$$

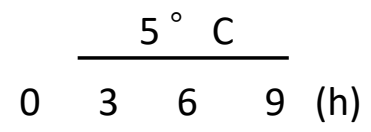

$m$
$\frac{n}{c}$
$\frac{1}{0}$
$\frac{1}{0}$
$\frac{0}{x}$ 
Figure 5D

\section{Anti-GFP}

뜰

\section{CBB staining}

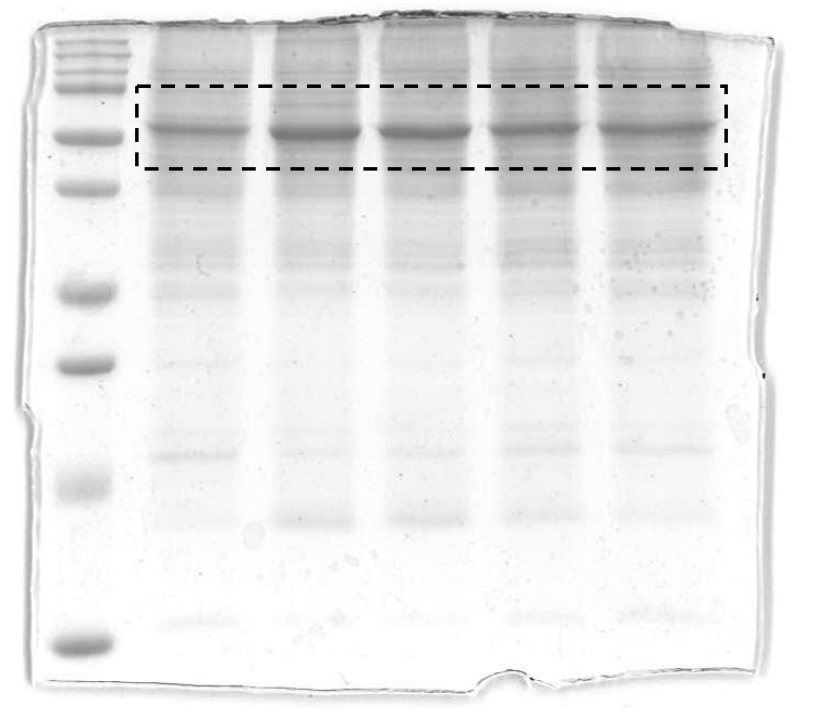

(h)

$N$
$\frac{1}{u}$
$\frac{\varepsilon}{\bar{c}}$
$\frac{y}{x}$
$\frac{\varrho}{u}$

$0 \frac{5^{\circ} \mathrm{C}}{36} \frac{22^{\circ} \mathrm{C}}{36}$

(h)

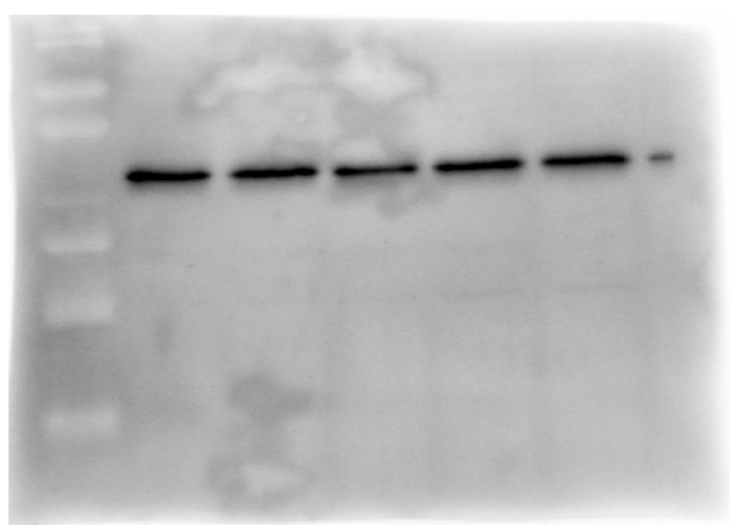

(h)

$m$
$\frac{n}{1}$
$\frac{\varepsilon}{\bar{c}}$
$\frac{1}{y}$
$\frac{\varrho}{x}$ 


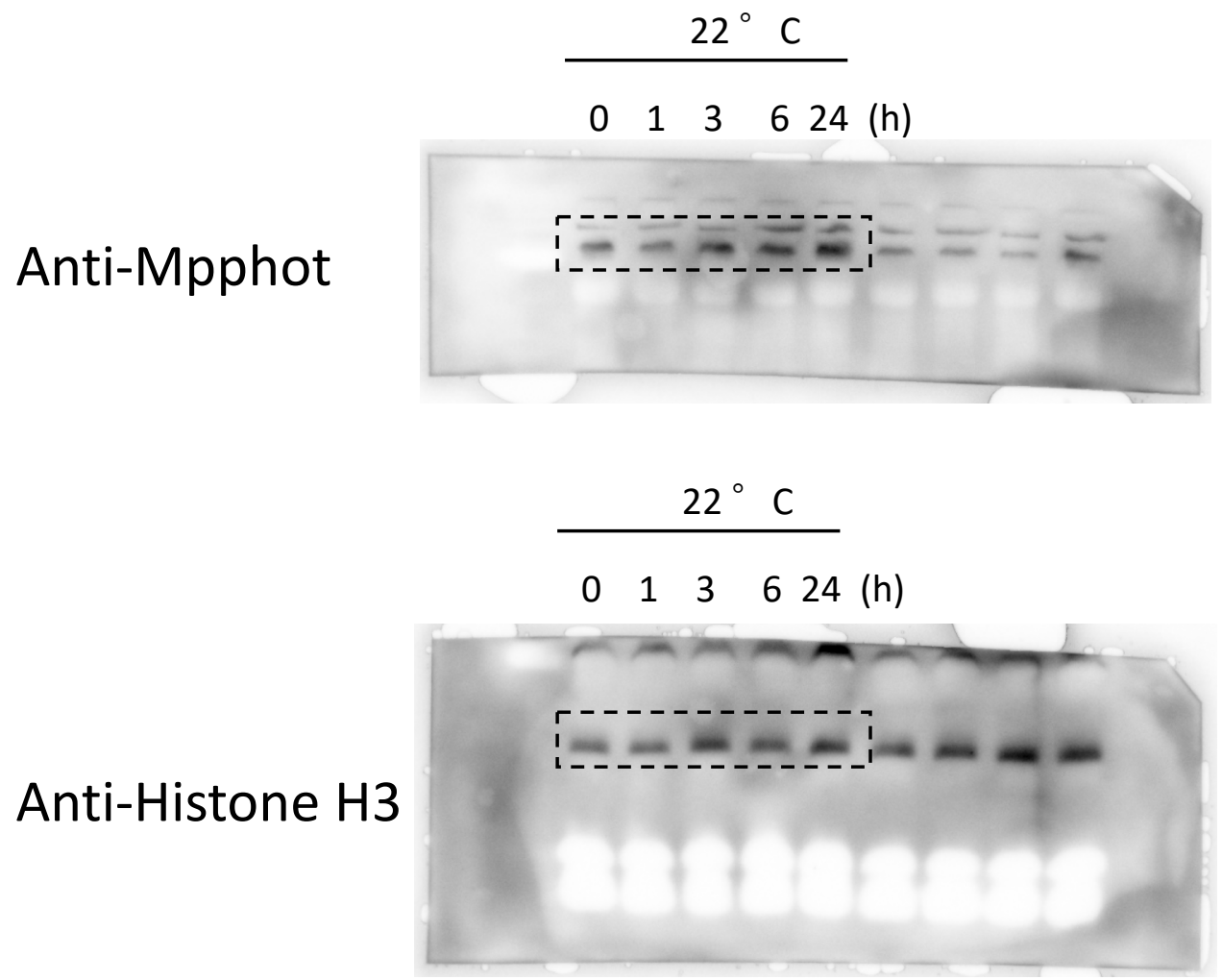

